\title{
Benchmark selection and performance
}

Citation for published version (APA):

Broeders, D., \& De Haan, L. (2020). Benchmark selection and performance. Journal of Pension Economics \& Finance, 19(4), 511-531. [1474747219000246].

https://doi.org/10.1017/S1474747219000246

Document status and date:

Published: 01/10/2020

DOI:

10.1017/S1474747219000246

Document Version:

Publisher's PDF, also known as Version of record

Document license:

Taverne

Please check the document version of this publication:

- A submitted manuscript is the version of the article upon submission and before peer-review. There can be important differences between the submitted version and the official published version of record.

People interested in the research are advised to contact the author for the final version of the publication, or visit the DOI to the publisher's website.

- The final author version and the galley proof are versions of the publication after peer review.

- The final published version features the final layout of the paper including the volume, issue and page numbers.

Link to publication

\footnotetext{
General rights rights.

- You may freely distribute the URL identifying the publication in the public portal. please follow below link for the End User Agreement:

www.umlib.nl/taverne-license

Take down policy

If you believe that this document breaches copyright please contact us at:

repository@maastrichtuniversity.nl

providing details and we will investigate your claim.
}

Copyright and moral rights for the publications made accessible in the public portal are retained by the authors and/or other copyright owners and it is a condition of accessing publications that users recognise and abide by the legal requirements associated with these

- Users may download and print one copy of any publication from the public portal for the purpose of private study or research.

- You may not further distribute the material or use it for any profit-making activity or commercial gain

If the publication is distributed under the terms of Article $25 \mathrm{fa}$ of the Dutch Copyright Act, indicated by the "Taverne" license above, 


\title{
ARTICLE
}

\section{Benchmark selection and performance}

\author{
Dirk Broeders ${ }^{1,2 *}$ and Leo de Haan ${ }^{1}$ \\ ${ }^{1}$ De Nederlandsche Bank, Amsterdam, The Netherlands and ${ }^{2}$ Maastricht University, Maastricht, The Netherlands \\ ${ }^{*}$ Corresponding author. Email: d.w.g.a.broeders@dnb.nl
}

(Received 10 January 2019; revised 9 September 2019; accepted 4 October 2019; first published online 12 November 2019)

\begin{abstract}
Using regulatory data free of self-reporting bias for 2007-16, we decompose investment returns of 455 Dutch pension funds according to their key investment decisions, i.e., asset allocation, market timing and security selection. In extension to existing papers, we also assess the impact of benchmark selection. Over time, asset allocation explains $39 \%$ of the variation of returns, whereas benchmark selection, timing and selection explain $11 \%, 9 \%$ and $16 \%$, respectively. Across pension funds, asset allocation explains on average only $19 \%$ of the variation in pension fund returns. Benchmark selection dominates this by explaining $33 \%$ of cross-sectional returns. We relate the choice for a specific benchmark to investment, risk and style preferences.
\end{abstract}

Key words: Asset allocation; benchmark selection; investment performance; pension funds

JEL codes: G11; G23

\section{Introduction and contribution}

Pension fund trustees make important decisions on behalf of the pension fund's participants. Setting the investment policy is one of the most important decisions to be made by the trustees, next to liability hedging, contribution and pension benefit policy. The investment policy itself includes several key decisions affecting investment returns: the choice of the strategic asset allocation, the timing of investment decisions and security selection. The board of trustees is responsible for setting the overall strategic policy. Although the board of trustees is also responsible for the implementation of its investment policy, it typically delegates this to internal and external investment managers, see Van Binsbergen et al. (2008).

The economic purpose of decomposing investment returns is to estimate the incremental impact each of the decisions has on the overall return. This is relevant for pension funds' participants whose contributions and benefits ultimately depend on the investment returns over time. Furthermore, return decomposition explains return differences across pension funds. In comparison with previous studies on the impact of investment decisions on returns, we present an innovation in the decomposition of returns. In addition to the usual decomposition into asset allocation, market timing and security selection, we analyse the impact of benchmark selection. The benchmark not only defines the universe of a pension fund's eligible investments, but also provides a guideline for performance evaluation and manager compensation. Often such benchmarks are custom built for an investor. In the remainder of this paper we therefore call such a benchmark a proprietary benchmark. By contrast, a standard benchmark will typically capture the entire opportunity set of investments in a market, sector or asset class. Standard benchmarks are offered by commercial vendors. The difference between a proprietary benchmark and a standard benchmark therefore captures the effect of differences in investment universe on returns and risk. We expect benchmark selection to explain return variations in the cross-section of pension funds as it measures pension fund specific preferences 
and choices. The asset allocation decision, by contrast, explains return variations in the time-series as pension funds all have exposure to the same market returns.

There are several motives for pension funds to choose a proprietary benchmark. A first motive is that the proprietary benchmark reflects the investment preferences of the pension fund's participants. A pension fund may, e.g., exclude certain sectors in the economy from its investment universe. For example, participants may not wish to have a strategic exposure to 'sin stocks'. These stocks are found in sectors that are perceived to make money from exploiting human weaknesses and frailties, e.g., alcohol, tobacco and gambling. For this reason, such a pension fund may wish to use a proprietary benchmark that can be derived from a standard benchmark by excluding these exposures. A second motive is risk preferences. A pension fund that decides to invest only in investment grade debtors may consequently use a matching proprietary bond benchmark for return analysis. Standard benchmarks for bonds typically overweigh countries and other debtors that issue significant amounts of debt. Especially if these benchmarks are value weighted and therefore perceived to be more risky. A third motive is that the pension fund has specific investment expertise or style preferences. An example is a pension fund having substantial expertise in and exposure to 'green' real estate and therefore uses a proprietary benchmark for returns analysis. The benchmark can also be tailored to the pension funds' specific investment style, such as growth investing or value investing. A fourth motive is the strategic incentive to select an 'easy-to-beat' benchmark. If the performance fee of an active asset manager is based on outperforming the benchmark, there is an incentive to create a proprietary benchmark that is easy to beat. Institutional investors may, e.g., compare hedge-fund returns to, so-called, cash-based benchmarks, such as Libor plus a $4 \%$ fixed return. These cash-based benchmarks have serious flaws, see, e.g., Heale et al. (2018). They have a low correlation with true hedge fund returns, are not investable, and therefore easy to beat. We focus on the first three motives in this paper.

We analyse the impact of benchmark selection on performance in a specific case study, the Dutch occupational pension system. These occupational pensions are the second pillar in a three-pillar structure. The first pillar is mandatory state-sponsored old-age income insurance and the third pillar is personal retirement savings. With 1,281 billion euros in assets under management at the end of 2016Q3, the Dutch occupational pension sector amounts to $187 \%$ of the GDP of the Netherlands. According to OECD (2017), the Dutch occupational pension system in 2017 represents 54\% of total pension assets in the euro area. The vast majority of pension funds in the system offer defined benefit schemes; see Broeders and Ponds (2012). They promise highly secure pension benefits to individuals, based on the number of years of service and the annual accrual rate. Market and longevity risks are borne collectively and absorbed by adjusting indexation and contributions. These adjustments are contingent on the ratio of assets over liabilities, both valued marked-to-market. Most (former) employees participate in industry-wide pension funds that execute the pension plan for a specific sector or industry. In addition, there are company pension funds providing pension plans to the employees of a single company and professional group pension funds offering pension schemes to specific professional groups (e.g., general practitioners and pharmacists). The occupational system has limited freedom of choice. Membership of an industry-wide pension fund is made mandatory for companies in certain industries, including the government and the health care and welfare sector. In addition, for most employees, pension plan participation is linked to the labour contract. This ensures that there is no competition between pension funds. Employees who would want to change pension funds have to change jobs. This often entails changing sectors also. Pension funds thus do not have a strong incentive to outperform a benchmark to attract new investors' capital.

This makes Dutch pension funds' investment behaviour an interesting subject for further analysis. We use data free of self-reporting bias, as the law requires the pension funds in our sample to report policy and actual statistics on asset allocations and returns for regulatory purposes. Most pension funds also report publicly on their investment performance through annual and quarterly reports and their website, although the law does not require this. Dutch pension funds are not exposed to any quantitative investment restrictions and in practice diversify across a wide variety of different 
asset classes. ${ }^{1}$ Investment policy needs to be compliant with the prudent person rule, which demands that pension funds invest in the best interest of their participants, taking into account sufficient diversification, liquidity and quality of the investment portfolio. With our unique data we can determine the impact of different investment decisions on returns. Following the literature on return decomposition, we analyse pension funds' returns from five different angles:

(1) Return decomposition. We decompose pension fund returns into asset allocation policy, market timing and security selection. We extend the seminal framework of Brinson et al. (1986) by adding the impact of benchmark selection.

(2) Contributions to return variation. We unravel the impact of asset allocation policy, benchmark selection, market timing and security selection on time series and cross-sectional return variation following Brown et al. (2010).

(3) Contributions to return variation net of market movements. Similar to 2, but net of market returns.

(4) Returns from actively changing strategic asset allocation. We decompose the time series and cross-sectional return variation with changes in strategic asset allocation following Andonov et al. (2012).

(5) Risk-adjusted returns from actively changing strategic asset allocation. Similar to 4, using risk-adjusted returns.

The types of decisions that investors can make differ in terms of their time dimension. Asset allocation policy, benchmark selection, market timing and security selection all concern point in time decisions. Changing the strategic asset allocation, by contrast, concerns a decision over time. The plan of this paper is as follows. After reviewing the relevant literature in Section 2, we present our methodology in Section 3. In Section 4 we discuss the data, after which we give our analysis of portfolio returns in Sections 5 and 6. In Section 7 we map benchmark selection and pension fund characteristics. Section 8 provides a robustness check and Section 9 concludes.

\section{Literature review}

This paper adds to the strand of literature on return decomposition. The classical paper of Brinson et al. (1986) decomposes quarterly returns of 91 US pension funds during 1974-83 into returns due to asset allocation, market timing and security selection. The authors calculate the respective contributions of each of those decisions to the return variation across time. They find that asset allocation policy contributes the bulk of variation across time. In an update for 82 US pension funds over 197787, Brinson et al. (1991) confirm this finding. Ibbotson and Kaplan (2000) show that the greater part of the vast contribution of asset allocation policy to return variation across time is due to general developments in the capital markets, not to the pension funds' specific asset allocation policies. They also calculate contributions to return variation among pension funds, for which asset allocation policy contributes less. These results are confirmed by Andreu et al. (2010).

Drobetz and Köhler (2002) analysed German and Swiss balanced mutual funds' data. The authors document that the largest part of return variability over time and across mutual funds is explained by asset allocation policy. They show that the policy return level explains more than $100 \%$ of the return level. Brown et al. (2010) apply an analysis of asset allocation, market timing and security selection on university endowment funds in the USA, Canada and Puerto Rico over the period 1984-2005. They show that the risk-adjusted excess performance of the average endowment is negligible. Xiong et al. (2010) show that market movements should be removed to analyse the pension fund specific characteristics by using excess market returns in time series analysis.

\footnotetext{
${ }^{1}$ The only investment restriction is that pension funds cannot invest more than $10 \%$ of total assets in the pension fund's sponsor.
} 
Blake et al. (1999) studied WM Company data for 306 UK pension funds. They find that strategic asset allocation decisions account for most of the time-series variation in the pension funds' portfolio returns. Clare et al. (2010) find that the investment performance of defined benefit pension funds in the UK is generally better than those reported in the literature for managers of mutual funds. Andonov et al. (2012) decompose returns and measure risk-adjusted performance of pension funds in the USA and Canada over 1990-2008 provided by CEM Benchmarking. They find that security selection explains most of the differences in pension fund returns and that large pension funds provide more value for their clients after accounting for investment-related costs, both before and after risk-adjusting.

There are a few papers on Dutch pension funds. Bikker et al. (2010) focus on the impact of market timing on pension fund returns in the Netherlands. They conclude that the average contribution of market timing to returns is zero to negative. Huang and Mahieu (2012) studied investment performance of about 60 industry-wide Dutch pension funds over 1998-2006. These pension funds are obliged to report their investment performance according to the so-called $z$-score. ${ }^{2}$ The authors find that pension funds as a group cannot beat their self-reported benchmarks consistently. Gerritsen (2016), analysing equity investments of around 660 Dutch pension funds over 1999-2015, confirms this finding. Broeders et al. (2017) find no statistical evidence that the returns of pension funds that pay performance fees for active investments are significantly higher or lower than the returns of pension funds that do not pay performance fees. Our paper decomposes returns, return variation and risk-adjusted returns by investment policy across 2007-16 for all types of Dutch pension funds, looking at all four broad asset classes: bonds, equities, real estate and other.

\section{Asset allocation policy, benchmark selection, market timing and security selection}

Our point of departure is the methodology introduced by Brinson et al. $(1986,1991)$ to decompose returns into the components: asset allocation policy, market timing and security selection. ${ }^{3}$ Blake et al. (1999), Brown et al. (2010), Xiong et al. (2010) and Andonov et al. (2012) all follow this approach. Instead of using this approach directly we extend it by including a fourth component, i.e., benchmark selection to capture the impact of choosing the investable universe. This way we take into account that each pension fund may use its own proprietary benchmark. The proprietary benchmark contributes significantly to a pension fund's return and return variation, as it is directly linked to the pension fund's holdings even though actively managed portfolios can deviate from the benchmark. The composition, and therefore the return and risk characteristics of this proprietary benchmark, deviates from standard benchmarks. However, we expect the return correlation between the proprietary benchmark and the standard benchmark to be high, especially in bonds and equities.

Our approach is as follows. The realised total portfolio return of pension fund $i$ in period $t$ can be written as:

$$
R_{i, t}=\sum_{j=1}^{M} w_{i, j, t-1} r_{i, j, t},
$$

where $w_{i, j, t-1}$ is the actual portfolio weight of pension fund $i=1, \ldots, N$ in asset class $j=1, \ldots, M$ at the end of period $t-1$, and $r_{i, j, t}$ the realised period- $t$ return of pension fund $i$ on asset class $j$. The realised total portfolio return can be decomposed into the impact of the underlying decisions in the following way. When $w_{i, j, t-1}^{A A}$ is the strategic asset allocation weight of pension fund $i$ in asset class $j, r_{j, t}^{S B}$ the

\footnotetext{
${ }^{2}$ The $z$-score measurers the investment performance of an industry-wide pension funds against a return of predefined portfolio that takes into account the risk profile of the pension fund.

${ }^{3}$ We assume readers are familiar with the seminal approach of Brinson et al. (1986). We note that Brinson et al. (1986) have an interaction term in their model. The reason for this interaction term is that these authors decompose the excess return rather than the absolute portfolio return. It can be shown mathematically that the interaction term does not appear if one decomposes the absolute, rather than the excess, returns.
} 
standard benchmark return on asset class $j$ and $r_{i, j, t}^{P B}$ the proprietary benchmark return of pension fund $i$ on asset class $j$, equation (1) can be decomposed into the following four components:

$$
\begin{aligned}
R_{i t} & =\sum_{j=1}^{M} w_{i, j, t-1}^{A A} r_{j, t}^{S B}+\sum_{j=1}^{M} w_{i, j, t-1}^{A A}\left(r_{i, j, t}^{P B}-r_{j, t}^{S B}\right)+\sum_{j=1}^{M}\left(w_{i, j, t-1}-w_{i, j, t-1}^{A A}\right) r_{i, j, t}^{P B}+\sum_{j=1}^{M} w_{i, j, t-1}\left(r_{i, j, t}-r_{i, j, t}^{P B}\right) \\
& \equiv R_{i, t}^{A A}+R_{i, t}^{B S}+R_{i, t}^{M T}+R_{i, t}^{S S},
\end{aligned}
$$

where $R_{i, t}^{A A}$ is the portfolio return from asset allocation policy based on the standard benchmark, $R_{i, t}^{B S}$ is the additional portfolio return from benchmark selection given that the pension funds invests according to its strategic weights, $R_{i, t}^{M T}$ is the portfolio return from market timing based on the proprietary benchmark return and $R_{i, t}^{S S}$ is the portfolio return from security selection based on the actual portfolio weights. Note that the decomposition in (2) is an identity relation: the sum of the four components by construction delivers exactly the realised total portfolio return of a pension fund. Using such an identity relation means that the return can be fully attributed to the different decisions an investor makes. Figure 1 shows the dependencies of the variables in equation (2).

A pension fund's asset allocation policy return is a consequence of the investment policy adopted by the board of trustees if it would invest in standard benchmarks. The investment policy identifies the strategic asset allocation selected to meet a pension fund's objectives and to control the overall risk. This includes the selection of asset classes and strategic weights. To calculate the asset allocation policy return, we use the strategic asset allocation weights of all asset classes and a standard benchmark return assigned to each asset class.

The return from benchmark selection captures the choice of the investment universe. It follows from the decision of the pension fund to have a proprietary benchmark that deviates from a standard benchmark. Suppose a pension fund restricts its investment universe and does not invest in carbon intensive industries. In that case it will create a proprietary benchmark excluding this industry. This way the actual return can be fairly assessed against the return on the proprietary benchmark. According to the fundamental law of active management of Grinold and Kahn (2000), the risk-adjusted extra return over a passive return equals the predictive power of the asset manager times the square root of the number of independent investment decisions. This law suggests that the return potential from benchmark selection is small as it involves only a single investment decision.

The return from timing is the return of under- or overweighting an asset class relative to its strategic asset allocation weight. Its purpose is to enhance return or to reduce risk. Timing is undertaken to achieve incremental returns relative to the asset allocation policy return. If timing is bad, it decreases returns. Grinold and Kahn (2000) show that the potential extra return through market timing is limited. This again follows from the fundamental law of active management. If a pension fund makes quarterly market timing decisions, the annual number of independent investment decisions is four. It requires a highly predictive power for the pension funds to earn an excess return based on these four timing decisions.

The return from security selection is obtained by means of actively selecting securities within an asset class. It is defined as the portfolio's actual asset class returns versus the passive proprietary benchmark returns and weighted by the strategic asset allocations. However, according to the fundamental law of active management the return potential is larger. Security selection out of thousands of different stocks, bonds and other assets means that the number of independent investment decisions is high. As a consequence, a pension fund requires only small predictive power ('skills') to earn a risk-adjusted excess return.

\section{Data}

After the theoretical considerations in the previous section, we now turn to the data that we will use for analysing portfolio performance. We use quarterly unbalanced panel data on 480 Dutch pension funds' investments and returns during the period 2007Q1-2016Q3. The returns are net of 


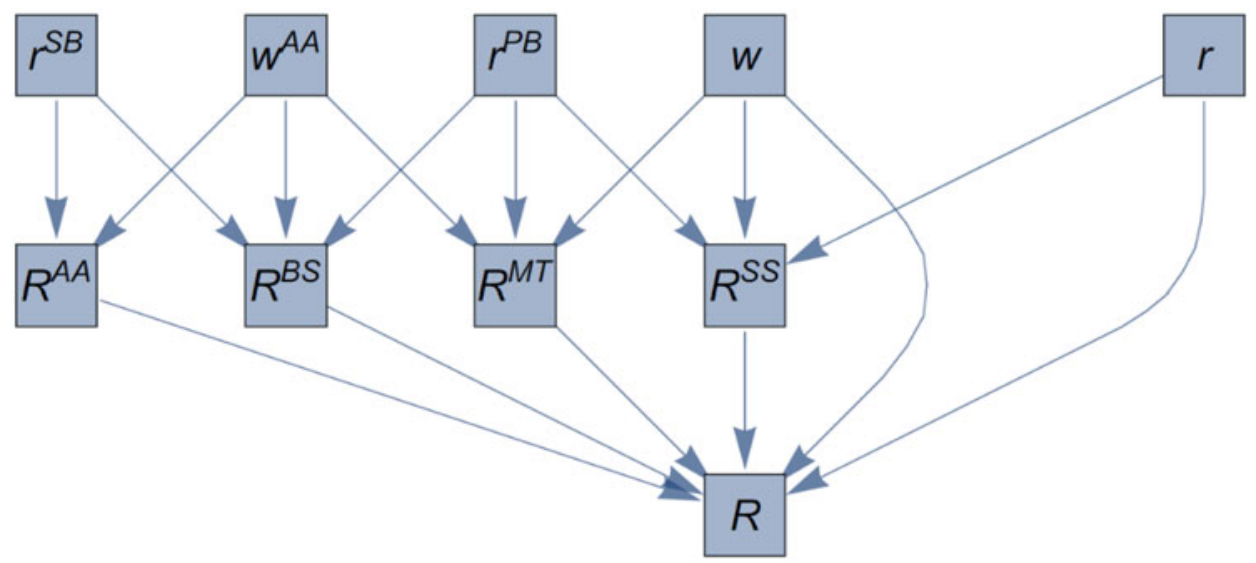

Figure 1. (Colour online) Dependencies of the variables in Equation (2). This figure shows how the realised total portfolio return $R$ is determined by the four investment decisions (subscripts are suppressed for ease of exposition). $R^{A A}$ is the portfolio return from asset allocation policy based on the standard benchmark return $r^{S B}$ and the strategic asset allocation $w^{A A}$. $R^{B S}$ is the additional portfolio return from benchmark selection. This additional return is a function of the proprietary benchmark return $r^{P B}$ minus the standard benchmark return and the strategic asset allocation. The additional return from market timing $R^{M T}$ is a function of the proprietary benchmark return and the deviation of actual asset allocation $w$ from strategic asset allocation $w^{A A}$. Finally, the additional return from security selection $R^{S S}$ is determined by the actual allocation $w$ and the actual return $R$.

management costs and performance fees. Pension funds are exempted from any capital gain tax. The 480 pension funds represent $86 \%$ of the Dutch pension sector in terms of total investments. The proprietary data have been obtained from the supervisory statistics of De Nederlandsche Bank, which is the prudential supervisor of pension funds in the Netherlands.

We distinguish four asset classes that sum up to the total portfolio: (1) bonds, (2) equities, (3) real estate and (4) other. Bonds include both government and corporate bonds. Equities include listed stocks and private equity. Real estate covers direct real estate, indirect non-listed real estate and indirect listed real estate. The category other includes cash, hedge funds, commodities, etc. ${ }^{4}$ The asset class portfolios of the pension funds in our sample can either be actively or passively managed. For all four classes, we have pension fund-specific data on actual net returns, actual asset allocations, strategic asset allocations and proprietary benchmark returns. ${ }^{5}$ This makes our data quite unique. For example, Brinson et al. $(1986,1991)$ lack details on strategic asset allocations. Therefore, they assume that the 10 -year average holding of each asset class was sufficient to approximate the strategic holding. They also do not have proprietary benchmark returns for each asset class for each pension fund. Therefore, they use standard market index returns for benchmark returns. Furthermore, they do not have complete data coverage on the 'other' category, so that they exclude this asset class from their analysis. Bauer et al. (2010) and Andonov et al. (2012) have pension fund proprietary benchmarks for US and Canadian pension funds but reporting in their sample is voluntary, not mandatory.

We clean the data for possible reporting errors and omissions. For that we reconcile and compare the actual reported portfolio return $R_{i t}$ and the reported strategic return $R_{i t}^{A A}$ with the outcomes of our own calculations of $R_{i t}$ and $R_{i t}^{A A}$, according to the right hand side of identity (1) and the strategic weights and proprietary benchmark returns, respectively. We then determine the 5th and 95th percentiles of the

\footnotetext{
${ }^{4}$ We exclude the impact of 'overlay' structures. We do not take into account any interest rate hedging policy with interest rates swaps. Although these represent a synthetic allocation to bonds, these can only be assessed from a total balance sheet perspective, i.e., the assets and liabilities. In this paper, we focus on the assets of pension funds only.

${ }^{5}$ Although we have self-reported benchmark returns, we have no specific details on the composition of these proprietary benchmarks (DNB, 2011) as pension funds do not report on this. Furthermore, the return per asset class may be the combined result of the returns on separate mandates each with a specific benchmark. A pension fund may choose to have active and passive mandates within an asset class or across asset classes. We do not have detailed intelligence on mandates.
} 
distributions of the deviations from the two identities. We drop observations from the data for which the deviations from the two identities lie outside their respective 5th to 95th percentile range. In total we drop 25 pension funds completely, leaving 455 pension funds in the sample. In addition to reporting errors and omissions, the relatively large number of observations dropped can also be due to the impact of the currency overlay on the portfolio return. Pension funds may hedge some (or all) of their currency exposure with derivatives. The overall reported portfolio return includes the impact of the currency overlay. It is however not included in the returns on individual asset classes. This difference may impact the reconciliation of returns, especially in times of high volatility in exchange rates. We cannot differentiate between reporting errors and omissions versus the impact of currency overlay. As a robustness check we also run all our regressions using the full sample in Section 7.

Figure 2 shows the strategic and the actual asset allocation for the four asset classes in this study. There is some time variation in both the strategic and actual asset allocations. These do not match exactly as the actual allocation is driven by market movements and pension funds do not continuously rebalance their asset allocation (Bikker et al., 2010). On average, pension funds allocate more to bonds in comparison with the strategic asset allocation around the financial crisis in 2008 and since 2011. The equity allocation follows the strategic asset allocation policy more closely. The actual allocation to real estate however is smaller than the strategic asset allocation until 2011 and larger thereafter. Other investments are under-allocated after 2011. Asset allocations can vary over time and between pension funds. To get a feeling for this, Table 1 shows the standard deviation across pension funds and time, for the actual and strategic asset allocation weights, respectively. It is apparent from this table that the dispersion of weights is largest for bonds and smallest for real estate. Again, this dispersion can be driven by pension funds changing their asset allocation over time or pension funds having dissimilar asset allocations. ${ }^{6}$ The large variation presented in Table 1 indicates that there are sufficient time series and cross-sectional differences for our analysis.

Figure 3 shows the average quarterly realised returns and returns from asset allocation policy for the different asset classes and for the total portfolio return. Aggregate realised returns on average did not deviate much from returns from asset allocation policy, with the exception of other investment returns. Obviously, variation in equity returns is the largest for this most risky asset class. In the fourth quarter of 2008 pension funds on average lost more than $20 \%$ on their equity portfolio following the financial crisis. The fourth quarter of 2010 was particularly bad for bond returns following the euro debt crisis. The impact of both crises urged the pension funds to take recovery measures to safeguard future pension benefits (e.g., De Haan, 2018).

Pension funds report strategic returns on their proprietary benchmarks. For analysing the impact of benchmark selection we need standard benchmarks returns. For bonds we use the JPM Global Government Bond Index, for equities the MSCI World Index and for the real estate GPR 250 Index. ${ }^{7}$ All standard benchmark returns are total returns (coupons, dividends and other cash flows are reinvested) and converted into euro returns. Table 2 shows summary statistics of the difference between the returns on the proprietary benchmarks and these standard benchmarks. Obviously, on average, there is not much difference in the returns of these two types of benchmarks. The standard deviation of the return difference however reveals that there is quite some difference in returns over time and across pension funds. As there does not exist a standard benchmark for other investments, our calculation of the performance contribution of benchmark selection does not include other investments. $^{8}$

\footnotetext{
${ }^{6}$ For empirical evidence on the portfolio allocation of Dutch corporate pension funds, see for example Davis and De Haan (2012).

${ }^{7}$ Obviously there is some arbitrariness in choosing standard benchmarks. We tested several different standard benchmarks and the results are not materially influenced by the benchmark choice. The returns on the different benchmarks are highly correlated. All standard benchmark returns are based on total return indices in euros as pension funds also report total returns in euros. The MSCI returns are gross returns as pension funds are exempt from paying dividend taxes.

${ }^{8}$ Differences in duration can also explain differences in returns between the proprietary bond index and standard bond index. We however don't have information on the duration of the proprietary bond indices to correct for this.
} 

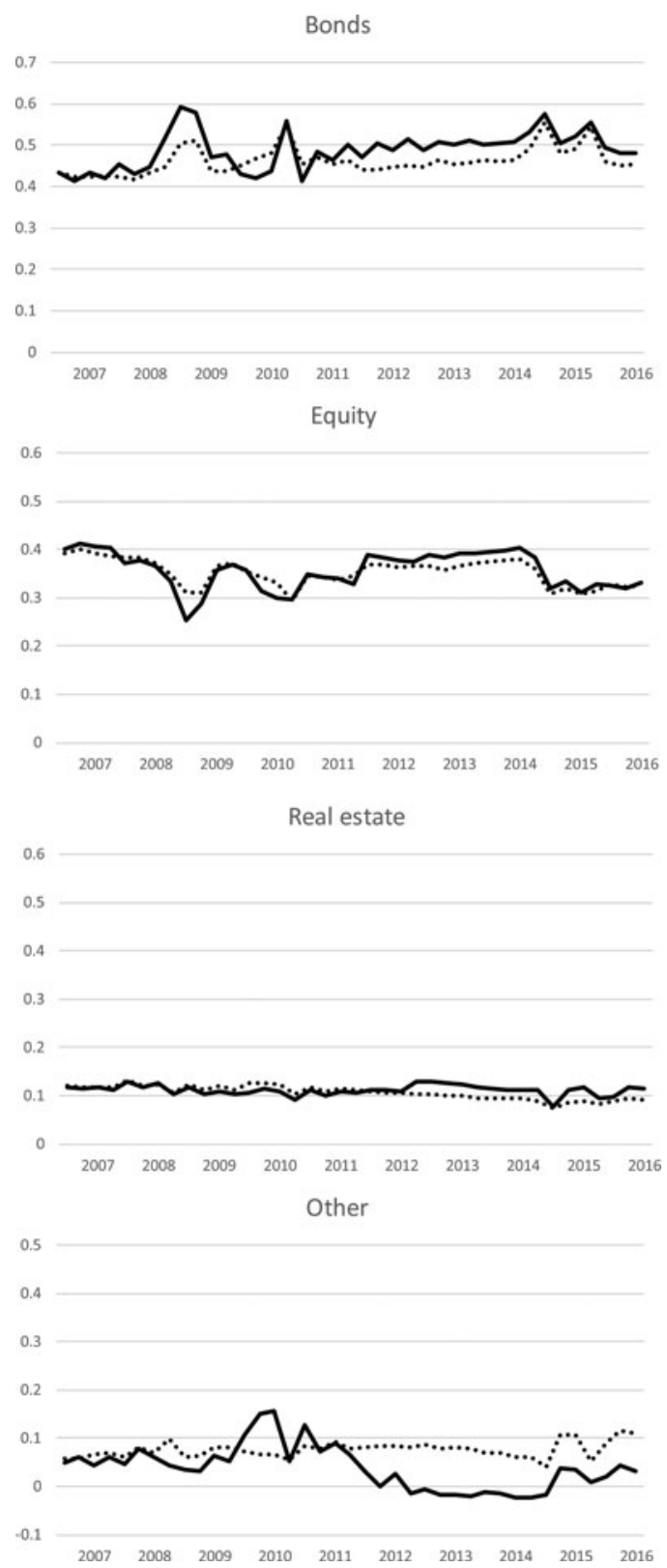

Figure 2. Average quarterly strategic and actual asset allocation.

Note: Weighted averages for 455 pension funds. Bold line is actual and dotted line is strategic. Averages are weighted by total assets under management.

To substantiate the differences in proprietary benchmarks, we calculated the fraction of pension funds that report a unique benchmark return. We calculated these fractions for bonds, equities and real estate for the first year in the sample (2007) and a year at the end of the sample (2015). The vast majority of pension funds use a unique benchmark. For instance for bonds, $83 \%$ of pension funds reported a unique benchmark return in 2007. In 2015 this has increased to $100 \%$, implying that all pension funds used a proprietary benchmark for bonds in that year. For equities and real estate the fraction of unique benchmark returns varies between $85 \%$ and $92 \%$. 
Table 1. Variation in asset allocation across pension funds and time

\begin{tabular}{lcc}
\hline Asset class & Strategic weights & Actual weights \\
\hline Bonds & 0.159 & 0.175 \\
Equity & 0.124 & 0.128 \\
Real estate & 0.059 & 0.057 \\
Other & 0.078 & 0.114 \\
\hline
\end{tabular}

Note: The table shows the standard deviations across both pension funds and time of strategic and actual allocation weights, respectively, for bonds, equities, real estate and other investments.

Table 2. Summary statistics of the difference between proprietary and standard benchmarks

\begin{tabular}{lccc}
\hline Asset class & Bonds & Stocks & Real estate \\
\hline Mean & 0.0033 & -0.0013 & -0.0144 \\
Median & 0.0049 & 0.0038 & -0.0168 \\
Std & 0.0398 & 0.0293 & 0.0929 \\
Correlation & 0.4646 & 0.9255 & 0.5016 \\
$N$ & 9,374 & 9,374 & 9,374 \\
\hline
\end{tabular}

Note: The table shows mean, median and standard deviation between the quarterly returns on the reported proprietary benchmarks and standard benchmarks. The correlation is the mean return correlation between the proprietary benchmark and the standard benchmark. For bonds we use the JPM Global Government Bond Index, for equities the MSCI World Index and for real estate GPR 250 Index. All benchmark returns are total returns in euros. $N$ is the number of observations.

\section{Analysis of pension fund portfolio returns}

After describing the data, we can now turn to the empirical analysis. We first present a decomposition of returns into asset allocation, benchmark selection, market timing and security selection in Section 5.1, followed by the measurement of the respective contributions to return variability in Section 5.2.

\subsection{Return decomposition}

Table 3 presents a decomposition of returns, using the framework presented in Section 3. For each year in the sample, quarterly means and standard deviations of actual returns of the pension funds are reported. Column (1) presents the mean actual returns and standard deviation. Column (2) gives returns from asset allocation policy based on standard benchmark returns. The active strategy can be split into benchmark selection, timing and selection in columns (3), (4) and (5), respectively. The contribution of policy, in column (6), is given by the difference between the active return and passive return $R-R^{A A}$ based on standard benchmark returns. Due to the unbalanced nature of the panel data, the numbers of pension funds vary over the years and are smaller than the total of 455 pension funds in the sample. The last row gives the means over the whole sample.

The average realised return over pension funds and time is $1.58 \%$ per quarter. This is equivalent to $6.47 \%$ per year over the $2007-16$ period. ${ }^{9}$ The financial crisis year 2008 was the only one with a negative return of $-9 \%$ annualised. The returns can be decomposed into four drivers following equation (2). The return from asset allocation policy is $1.30 \%$, the return from benchmark selection is $0.13 \%$, the return from market timing $0.10 \%{ }^{10}$ and $0.05 \%$ from selection. Measured over time and across pension funds, the strategic asset allocation and the standard benchmark returns constitute the bulk, namely $82 \%$, of actual returns. ${ }^{11}$ Benchmark selection has the second biggest positive contribution and determines $8 \%$ of total return over the whole sample. However, note that the benchmark policy contributes negatively in half of the years in our sample $(2008,2010,2011,2014$ and 2015). The active return contribution from timing and selection are slightly positive and comprise $6 \%$ and $3 \%$ of total return, respectively.

\footnotetext{
${ }^{9}(1+0.0158)^{4}-1=0.0647$.

${ }^{10}$ In Appendix A, we split the return contribution of timing into the contribution of over and underweight decisions. Pension funds are more successful when deciding to overweight a certain asset class compared to underweighting decisions.

${ }^{11} 1.30 / 1.58 \times 100 \%=82 \%$.
} 

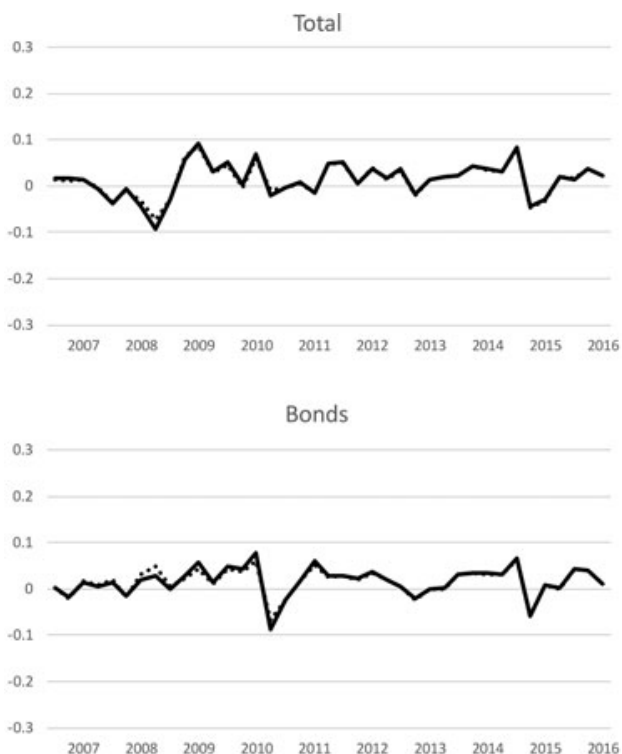

Equity
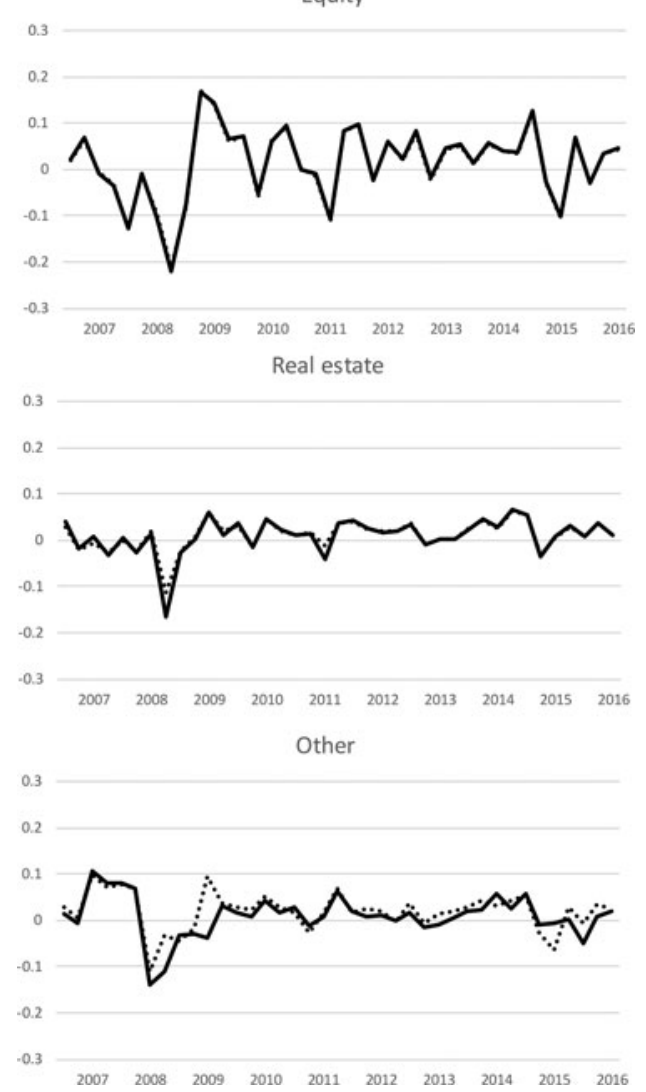

Figure 3. Average quarterly realised returns and returns from asset allocation policy, by asset class.

Note: Weighted averages for 455 pension funds. Bold line is actual realised returns and dotted line is return from asset allocation policy. Averages are weighted by total assets under management. 
Table 3. Return decomposition

\begin{tabular}{|c|c|c|c|c|c|c|c|c|c|}
\hline Year & & $\begin{array}{l}\text { Realised } \\
\text { return } \\
R\end{array}$ & $\begin{array}{c}\text { Asset allocation } \\
\text { policy } \\
R^{A A}\end{array}$ & $\begin{array}{c}\text { Benchmark } \\
\text { policy } \\
R^{B S}\end{array}$ & $\underset{R^{M T}}{\operatorname{Timing}}$ & $\begin{array}{c}\text { Selection } \\
R^{S S}\end{array}$ & $\begin{array}{c}\text { Policy } \\
\text { Contribution } \\
R-R^{A A}-R^{B S}\end{array}$ & $\begin{array}{l}\text { Number of } \\
\text { obs. }\end{array}$ & $\begin{array}{l}\text { (8) } \\
\text { Number of } \\
\text { pension } \\
\text { funds }\end{array}$ \\
\hline \multirow[t]{2}{*}{2007} & Mean & 0.0034 & -0.0026 & 0.0056 & 0.0008 & -0.0004 & 0.0003 & 1,223 & 381 \\
\hline & Std & 0.0142 & 0.0126 & 0.0117 & 0.0031 & 0.0078 & 0.0083 & & \\
\hline \multirow[t]{2}{*}{2008} & Mean & -0.0233 & -0.0192 & -0.0037 & 0.0044 & -0.0047 & -0.0003 & 982 & 350 \\
\hline & Std & 0.0284 & 0.0428 & 0.0337 & 0.0095 & 0.0167 & 0.0185 & & \\
\hline \multirow[t]{2}{*}{2009} & Mean & 0.0310 & 0.0192 & 0.0090 & -0.0004 & 0.0030 & 0.0026 & 1,157 & 364 \\
\hline & Std & 0.0469 & 0.0390 & 0.0219 & 0.0138 & 0.0178 & 0.0140 & & \\
\hline \multirow[t]{2}{*}{2010} & Mean & 0.0291 & 0.0388 & -0.0144 & 0.0010 & 0.0036 & 0.0046 & 1,008 & 325 \\
\hline & Std & 0.0414 & 0.0321 & 0.0531 & 0.0047 & 0.0196 & 0.0196 & & \\
\hline \multirow[t]{2}{*}{2011} & Mean & 0.0131 & 0.0125 & -0.0017 & 0.0005 & 0.0018 & 0.0023 & 1,000 & 324 \\
\hline & Std & 0.0342 & 0.0389 & 0.0278 & 0.0051 & 0.0173 & 0.0181 & & \\
\hline \multirow[t]{2}{*}{2012} & Mean & 0.0295 & 0.0136 & 0.0148 & 0.0004 & 0.0006 & 0.0011 & 1,055 & 312 \\
\hline & Std & 0.0220 & 0.0261 & 0.0334 & 0.0035 & 0.0089 & 0.0098 & & \\
\hline \multirow[t]{2}{*}{2013} & Mean & 0.0120 & 0.0030 & 0.0082 & 0.0006 & 0.0001 & 0.0007 & 1,028 & 286 \\
\hline & Std & 0.0215 & 0.0257 & 0.0146 & 0.0035 & 0.0053 & 0.0062 & & \\
\hline \multirow[t]{2}{*}{2014} & Mean & 0.0350 & 0.0386 & -0.0047 & 0.0013 & -0.0001 & 0.0011 & 910 & 266 \\
\hline & Std & 0.0157 & 0.0115 & 0.0158 & 0.0039 & 0.0068 & 0.0076 & & \\
\hline \multirow[t]{2}{*}{2015} & Mean & 0.0051 & 0.0165 & -0.0126 & 0.0005 & 0.0007 & 0.0012 & 550 & 188 \\
\hline & Std & 0.0185 & 0.0577 & 0.0211 & 0.0042 & 0.0104 & 0.0111 & & \\
\hline \multirow[t]{2}{*}{2016} & Mean & 0.0218 & 0.0173 & 0.0051 & 0.0001 & -0.0007 & -0.0006 & 461 & 177 \\
\hline & Std & 0.0151 & 0.0238 & 0.0202 & 0.0033 & 0.0064 & 0.0071 & & \\
\hline \multirow[t]{2}{*}{ Total } & Mean & 0.0158 & 0.0130 & 0.0013 & 0.0010 & 0.0005 & 0.0015 & 9,374 & 455 \\
\hline & Std & 0.0356 & 0.0368 & 0.0297 & 0.0069 & 0.0134 & 0.0133 & & \\
\hline \multirow[t]{2}{*}{ Total } & Mean & 0.0161 & 0.0140 & 0.0008 & 0.0014 & 0.0008 & 0.0026 & 12,230 & 480 \\
\hline & Std & 0.0928 & 0.0390 & 0.0368 & 0.0123 & 0.0791 & 0.0805 & & \\
\hline
\end{tabular}

Note: The table reports the summary statistics for pension funds' mean quarterly realised returns (mean) and standard deviations of returns (Std). Both are measured across time and pension funds. Following Equation (2) the successive columns show the average realised portfolio return $R$, the return contribution from asset allocation policy $R^{A A}$ based on standard benchmarks, the average return contribution from benchmark selection $R^{B M}$ based on proprietary benchmark returns, the average return contribution from market timing $R^{M T}$ and the average return contribution from security selection $R^{S S}$. The contribution of policy is given by the difference between the realised return and the returns from asset allocation and benchmark policy. All these numbers are averaged over four quarters and the number of pension funds in that year excluding possible reporting errors and omissions. The last two rows (Total) show the mean total returns and standard deviation using the full sample.

Timing on average only contributes negatively in 2009. Selection on average contributes negatively in 4 years of our sample. The relative importance of the asset allocation decision is consistent with theory and the existing literature. Obviously there is a wide dispersion of returns across pension funds. The standard deviation of the realised return over pension funds and time is $3.56 \%$ per quarter (or if we multiply by $\sqrt{4}$ it is equal to $7.12 \%$ annually). This is somewhat lower than the $3.68 \%$ standard deviation of the strategic policy. Also the standard deviation of the return from benchmark selection is quite large, with 2.97\% per quarter. This implies that the benchmark choices of pension funds are different.

\subsection{Contributions to return variation}

In the previous section, we analysed returns over time and across pension funds simultaneously. Following the methodology of Brinson et al. (1986, 1991), Ibbotson and Kaplan (2000), Xiong et al. (2010), Brown et al. (2010) and Andonov et al. (2012), in this section we quantify how much the different policy decisions contribute to return variation over time and across pension funds, separately. We determine the variability contribution over time by running the following regressions:

$$
R_{i, t}=a_{i}+b_{i} R_{i, t}^{k}+\varepsilon_{i, t}, \quad i=1, \ldots, N ; k=A A, B S, M T, S S
$$

where $N$ denotes the number of pension funds in our sample and $R_{i, t}^{k}$ is, in turn, $R_{i, t}^{A A}, R_{i, t}^{B S}, R_{i, t}^{M T}$ and $R_{i, t}^{S S}$. 
Table 4. Contributions to return variation

\begin{tabular}{lcccc}
\hline & Asset allocation & Benchmark selection & Market timing & Security selection \\
\hline Panel A. Time series $R^{2}$ values & & & & 0.111 \\
Mean & 0.394 & 0.072 & 0.094 & 0.159 \\
Median & 0.393 & -0.010 & 0.033 & 0.082 \\
25th percentile & 0.223 & 0.196 & -0.023 & 0.010 \\
75th percentile & 0.556 & 0.154 & 0.156 & 0.270 \\
Standard deviation & 0.230 & 344 & 344 & 344 \\
Number of observations (i.e., pension funds) & 344 & & & 0.221 \\
Panel B. Cross-sectional $R^{2}$ values & & 0.333 & 0.049 & 0.108 \\
Mean & 0.188 & 0.319 & 0.018 & 0.089 \\
Median & 0.155 & 0.210 & 0.005 & 0.032 \\
25th percentile & 0.058 & 0.438 & 0.082 & 0.166 \\
75th percentile & 0.280 & 0.196 & 0.064 & 0.092 \\
Standard deviation & 0.159 & 39 & 39 & 39 \\
Number of observations (i.e., quarters) & 39 & & \\
\hline
\end{tabular}

Note: The table shows the distribution of $R^{2}$ for the time series regression in Equation (3) in panel $\mathrm{A}$ and for the cross-sectional regression in Equation (4) in panel B. Panel A shows the return variation contribution over time and panel $B$ the return variation contribution across pension funds.

For each pension fund-specific time series regression, our interest goes to the coefficient of determination $R^{2}$, i.e., the contribution of the variation in the respective return component $R^{k}$ to the variation of the overall pension fund return $R$.

Similarly, the variability contribution across pension funds is determined by running the following cross-sectional regression for each quarter $t$ :

$$
R_{i, t}=a_{t}+b_{t} R_{i, t}^{k}+\varepsilon_{i, t}, \quad t=1, \ldots, T ; k=A A, B S, M T, S S
$$

Table 4 gives the results of these two tests. Panel A reports the summary statistics for the distribution of the adjusted $R^{2}$ coefficients for the time series regression (3), panel B reports for the quarterly crosssectional regression (4). Following Andonov et al. (2012), we drop $R^{2}$ coefficients from time-series regressions with only a few observations. Specifically, we set the minimum number of observations for the time-series regressions to 10, leaving 344 pension funds in that sample. Panel A shows that, on average, asset allocation explains $39.4 \%$ of the variation of pension funds' returns over time, whereas benchmark selection, timing and selection explain $11.1 \%, 9.4 \%$ and $15.9 \%$, respectively. Hence, the findings confirm the literature (e.g., Ibbotson and Kaplan (2000) for mutual funds, Brown et al. (2010) for university endowment funds) that asset allocation is the most important contributor to the variation in portfolio returns over time. However, in our analysis the importance is less paramount compared to these studies. Also note that security selection is more important compared to benchmark selection in explaining the time series variation in return.

However, as is apparent from these other studies as well, the picture changes when considering the results from the cross-sectional regression. Panel B shows that asset allocation explains on average only $18.8 \%$ of the cross-sectional variation in pension fund returns. Across pension funds benchmark selection, with $33.3 \%$, is dominant in explaining returns. Hence we conclude that benchmark selection matters in explaining cross-sectional return variations across pension funds. Timing contributes $4.9 \%$ and security selection is responsible for $10.8 \%$.

\subsection{Contributions to return variation net of market movements}

Overall market movements dominate the time series analysis of returns. Xiong et al. (2010) argue that 'the market' accounts for about $80-90 \%$ of the total returns variation. The next step in our analysis is to analyse the impact of asset allocation policy and benchmark selection net of market movements. Following Andonov et al. (2012) we first define the 'average policy return' $P R$ as the average of the 
equally weighted strategic asset allocation proprietary benchmark returns for a given quarter of all the pension funds in the dataset:

$$
P R_{t}=\frac{\sum_{i=1}^{N_{t}} \sum_{j=1}^{M} w_{i, j, t}^{A A} r_{i, j, t}^{P B}}{N_{t}}
$$

where $N_{t}$ represents the number of pension funds in year $t$ and the other notation is as before. The average policy return in (5) serves as a proxy of the market return. Based on this we can calculate the asset allocation returns and benchmark selection returns in excess of the market, respectively. In fact, we define the policy return based on the standard benchmark returns $\left(P B^{S B}\right)$ and the policy return differential based on the difference in return between the proprietary benchmark and the standard benchmark $\left(P R^{P B-S B}\right)$ as follows:

$$
\begin{gathered}
P R_{t}^{S B}=\frac{\sum_{i=1}^{N_{t}} \sum_{j=1}^{M} w_{i, j, t}^{A A} r_{j, t}^{S B}}{N_{t}} \\
P R_{t}^{P B-S B}=\frac{\sum_{i=1}^{N_{t}} \sum_{j=1}^{M} w_{i, j, t}^{A A}\left(r_{i, j, t}^{P B}-r_{j, t}^{S B}\right)}{N_{t}}
\end{gathered}
$$

Then, the decomposition of returns in excess of the market into our four components reads:

$$
\begin{aligned}
& R_{i t}^{\prime}=R_{i, t}-P R_{t} \\
& =\sum_{j=1}^{M}\left(w_{i, j, t-1}^{A A} r_{j, t}^{S B}-P R_{t}^{S B}\right)+\sum_{j=1}^{M}\left(w_{i, j, t-1}^{A A}\left(r_{i, j, t}^{P B}-r_{j, t}^{S B}\right)-P R_{t}^{P B-S B}\right) \\
& \quad+\sum_{j=1}^{M}\left(w_{i, j, t-1}-w_{i, j, t-1}^{A A}\right) r_{i, j, t}^{P B}+\sum_{j=1}^{M} w_{i, j, t-1}\left(r_{i, j, t}-r_{i, j, t}^{P B}\right) \\
& \equiv R_{i, t}^{A A^{\prime}}+R_{i, t}^{B S^{\prime}}+R_{i, t}^{M T}+R_{i, t}^{S S},
\end{aligned}
$$

Using excess returns, the regression equations (3) and (4) change to:

$$
\begin{aligned}
& R_{i t}^{\prime}=R_{i, t}-P R_{t}=a_{i}+b_{i} R_{i, t}^{k}+\varepsilon_{i, t}, \quad i=1, \ldots, N ; k=A A^{\prime}, B S^{\prime}, M T, S S \\
& R_{i t}^{\prime}=R_{i, t}-P R_{t}=a_{t}+b_{t} R_{i, t}^{k}+\varepsilon_{i, t}, \quad t=1, \ldots, T ; k=A A^{\prime}, B S^{\prime}, M T, S S
\end{aligned}
$$

Table 5 gives the time-series distribution of $R^{2}$ statistics for equation (7). The explanatory power of asset allocation of return variability is $22.6 \%$, which is 16.8 percentage points lower than in Table 4. As expected, removing market movements takes away part of the explanatory power of asset allocation. The contribution of benchmark selection increases by 24.2 percentage points to $35.3 \%$. After correcting for market movements, benchmark selection becomes more important in explaining time variation of returns. The results for market timing and selection do not change much as these are only indirectly affected in the estimation of equation (7) compared to equation (2). Table 5 does not give the cross-sectional distribution of $R^{2}$ for equation (8), as this is identical to that of equation (4) in panel B of Table 4. Cross-sectional regression already removes the influence of market movements. Again, benchmark selection supersedes asset allocation policy in explaining returns net of market movements. 
Table 5. Contributions to return variation net of market movements: time series $R^{2}$ values

\begin{tabular}{lcccc}
\hline & Asset allocation & Benchmark selection & Market timing & Security selection \\
\hline Mean & 0.226 & 0.353 & 0.102 & 0.150 \\
Median & 0.167 & 0.342 & 0.039 & 0.065 \\
25th percentile & 0.016 & 0.094 & -0.025 & -0.015 \\
75th percentile & 0.388 & 0.576 & 0.194 & 0.262 \\
Standard deviation & 0.244 & 0.282 & 0.172 & 0.223 \\
Number of observations (i.e., pension funds) & 344 & 344 & 344 & 344 \\
\hline
\end{tabular}

Note: The table shows the distribution of $R^{2}$ for the time series regression in Equation (7) in excess of the market. The distribution of $R^{2}$ for the cross-sectional regression in Equation (8) in excess of the market is identical to panel B of Table 4 as the cross-sectional regression already removes the influence of market movements.

\section{Analysis of pension fund portfolio returns and changes in the strategic asset allocation}

So far, we analysed the impact of point in time decisions on returns. By contrast it is also possible to analyse decisions that have an over time dimension. Pension funds for instance gradually change their strategic asset allocation over time. This is shown in Figure 2 and Table 1. Pension funds have multiple reasons for doing so. For instance because their liability structure changes, or their return and risk expectations of the different asset classes change. Changing the strategic asset allocation is also an active decision impacting returns. In this section, we estimate the impact from this active investment decision on returns, first as such and then with adjustment for risk.

\subsection{Returns from actively changing strategic asset allocation}

We define an active change in the strategic asset allocation as a quarter-on-quarter change in a strategic weight $\left(w^{A A}\right){ }^{12}$ Following Andonov et al. (2012), we estimate and evaluate the return implications from these active decisions made by the pension fund to modify the strategic asset allocation policy over time as follows:

$$
R_{i, t}^{\Delta A A}=\sum_{j=1}^{M}\left(w_{i, j, t}^{A A}-w_{i, j, t-1}^{A A}\right) r_{i, j, t}^{S B}
$$

This return component measures the return due to changes in strategic asset allocation policy over time, which is different from the asset allocation component used in the decomposition of pension fund returns (equations (2) and (6)). Similar to Andonov et al. (2012) we include the other active decisions made by the pension funds to deviate from standard benchmark returns: benchmark selection, market timing and security selection. These are identical to their respective components in equations (2) and (6):

$$
\begin{aligned}
R_{i, t}^{B S} & =\sum_{j=1}^{M} w_{i, j, t}^{A A}\left(r_{i, j, t}^{P B}-r_{i, j, t}^{S B}\right) \\
R_{i, t}^{M T} & =\sum_{j=1}^{M}\left(w_{i, j, t}-w_{i, j, t}^{A A}\right) r_{i, j, t}^{P B}
\end{aligned}
$$

\footnotetext{
${ }^{12}$ Pension funds typically reassess the strategic asset allocation every 3 years. However, we observe more frequent changes in strategic portfolio weights. There are at least two reasons for this. First, a large change in the strategic asset allocation may take several quarters or even years to implement. Pension funds may report in such a case gradual changes in the strategic asset allocation. Second, pension funds may have a dynamic asset allocation strategy in which strategic weights automatically follow some state-variables.
} 


$$
R_{i, t}^{S S}=\sum_{j=1}^{M} w_{i, j, t}\left(r_{i, j, t}-r_{i, j, t}^{P B}\right)
$$

Following Andonov et al. (2012), we run a random coefficient model with a constant only for the active return management components as defined in equations (9) through (12). Table 6 shows the constants and the corresponding $z$-statistic in parentheses. ${ }^{13}$ Andonov et al. (2012) find a positive $\alpha$ of 17 basis points per year from changes in strategic asset allocation, which is mainly observed among US pension funds. Interestingly, we do not find that changes in the strategic asset allocation policy produce additional returns for Dutch pension funds. A possible explanation for this difference is the following. Andonov et al. (2012) measured the change in the strategic asset allocation in relation to the proprietary benchmark return. By contrast, we measure the effect in relation to the standard benchmark return. This suggests that the abnormal return found by Andonov et al. (2012) may be captured by the impact of benchmark selection. To test the robustness of our finding we run an additional test. In $46 \%$ of observations pension funds did not change their strategic allocation policy from one quarter to the other. This means that $R^{\triangle A A}=0$, i.e. the dependent variable in the regression, is zero in those cases. If we run the regression for strategic asset allocation changes excluding zero changes, we still do not find an additional return from changes in strategic asset allocation over time. Only market timing delivers a statistically significant 0.089 basis points per quarter, but the economic impact is negligible. Benchmark selection and security selection do not yield a statistically significant return.

\subsection{Risk-adjusted returns from changing strategic asset allocation}

The performance measures in Table 6 do not adjust for risk. Therefore, we follow Andonov et al. (2012) by also presenting random coefficient model estimates that include multiple factors to assess whether the performance remains after risk adjusting. The model is:

$$
R_{i, t}^{k}=a_{i}+\sum_{f=1}^{5} \beta_{i, f} F_{t, f}+\varepsilon_{i, t}
$$

where $k=\triangle A A, B S, M T, S S$, and the dependent variables are as defined by equations (9)-(12), respectively. $F_{f}$ stands for quarterly factor returns $(f=1, \ldots, 5)$. In order to risk-adjust the pension fund portfolio performance, we use the following five global Fama and French (2015) factors: MKT-RF (the return on the value-weighted market portfolio minus the risk-free return), SMB (the return on a diversified portfolio of small stocks minus the return on a diversified portfolio of big stocks), HML (the difference between the returns on diversified portfolios of high and low book-to-market stocks), RMW (the difference between the returns on diversified portfolios of stocks with robust and weak profitability) and CMA (the difference between the returns on diversified portfolios of the stocks of low and high investment firms). Andonov et al. (2012) use the random coefficient model because it has as an important advantage that it allows for heteroscedasticity and pension fund-specific $\beta$ s, while being more robust to outliers than the standard Fama-MacBeth approach. As Swamy (1970) explains, the random coefficient model is similar to a generalised least squares model that puts less weight on the return series that are more volatile.

Results in Table 7 show the quarterly $\alpha$ (i.e., the constant) and $\beta$ coefficients on these factors. After risk-adjusting, the changes in asset allocation policy still do not deliver a positive $\alpha$. Also not in the case where we exclude zero change observations. These outcomes do not differ from the results before

\footnotetext{
${ }^{13}$ The number of pension funds drops to 413 due to the transformation as in equation (9).
} 
Table 6. Returns from actively changing strategic asset allocation

\begin{tabular}{|c|c|c|c|}
\hline & Constant & Number of obs. & Number of pension funds \\
\hline Change in asset allocation & $\begin{array}{r}0.00004 \\
(0.82)\end{array}$ & 7,619 & 413 \\
\hline $\begin{array}{c}\text { Change in asset allocation, } \\
\text { non-zero changes only }\end{array}$ & $\begin{array}{r}0.00011 \\
(0.74)\end{array}$ & 3,020 & 311 \\
\hline Benchmark selection & $\begin{array}{r}0.00009 \\
(1.43)\end{array}$ & 7,619 & 413 \\
\hline $\begin{array}{l}\text { Benchmark selection, } \\
\text { non-zero changes only }\end{array}$ & $\begin{array}{r}0.00024 \\
(1.03)\end{array}$ & 3,020 & 311 \\
\hline Market timing & $\begin{array}{l}0.00089^{\star \star \star} \\
(7.77)\end{array}$ & 9,356 & 437 \\
\hline Security selection & $\begin{array}{r}0.00022 \\
(1.07)\end{array}$ & 9,356 & 437 \\
\hline
\end{tabular}

Note: Random coefficient estimates of the constants for the change in asset allocation, benchmark selection, market timing and security selection. $z$-values are given in parentheses. ${ }^{* \star},{ }^{* \star},{ }^{*}$ denote significance at the $1 \%, 5 \%, 10 \%$ levels.

risk adjustment and are economically insignificant. ${ }^{14}$ Also note that the $\beta$ s of the five factors are insignificant for this return component.

Benchmark selection and market timing after risk-adjusting deliver a positive $\alpha$ of 0.01 and 0.11 basis points, respectively. Notice however that market timing has a positive loading on the SMB and CMA factors and a negative loading on the market and HML factors. All four factors are statistically significant. Security selection again does not yield a statistically significant return. Contrary to market timing, security selection has a positive factor loading on the market and a negative on CMA. If we exclude zero changes, we observe that benchmark selection loads negatively on HML.

\section{Benchmark selection and pension fund characteristics}

We argued in Section 1 that several motives exist for pension funds to choose a proprietary benchmark. These motives relate to investment, risk, style or strategic preferences. We conjecture that pension funds with stronger investment beliefs will choose a more distinct proprietary benchmark. Although we are not able to test these motives directly, as these preferences are not observable, we can analyse the extent to which pension fund characteristics influence benchmark selection. This way we assume that pension funds' characteristics correlate with investment beliefs. The standard deviation of the return difference between this proprietary and standard benchmark will consequently be higher. We run the following Tobit regression:

$$
\begin{gathered}
\sigma_{i, j}=\alpha+\beta_{j, 1} \text { Size }_{i}+\beta_{j, 2} \text { Age }_{i}+\beta_{j, 3} \operatorname{Ind}_{i}+\beta_{j, 4} \operatorname{Corp}_{i}+\varepsilon \\
i=1, \ldots, N ; j=1, \ldots, 3
\end{gathered}
$$

where $\sigma_{i, j}$ is the standard deviation of the quarterly return differences between the reported proprietary and standard benchmarks for pension fund $i$ for asset class $j$ over the sample period, Size $e_{i}$ the log of the average size of pension fund $i$ over the sample period, $A g e_{i}$ the average ratio of pensioners to total participants, $\operatorname{Corp}_{i}$ a dummy for corporate pension funds and $I n d_{i}$ a dummy for industry-wide pension funds.

Regarding investment style preferences, we hypothesise that large pension funds are less likely to have style preferences for mechanical diversification reasons, that pension funds with an old population have stronger investment preferences because the engagement of retirees is generally stronger, and that industry-wide pension funds have stronger investment preferences because of reputational

\footnotetext{
${ }^{14}$ The numbers of observations and pension funds are lower than before risk-adjusting, as the number of panels that are too small for random coefficients regression increases.
} 
Table 7. Risk-adjusted returns from actively changing strategic asset allocation

\begin{tabular}{|c|c|c|c|c|c|c|}
\hline & \multicolumn{6}{|c|}{ Return component: } \\
\hline & $\begin{array}{c}\text { Change in } \\
\text { asset allocation }\end{array}$ & $\begin{array}{c}\text { Change in } \\
\text { asset allocation, } \\
\text { non-zero changes } \\
\text { only }\end{array}$ & $\begin{array}{l}\text { Benchmark } \\
\text { selection }\end{array}$ & $\begin{array}{l}\text { Benchmark } \\
\text { selection, } \\
\text { non-zero } \\
\text { changes only }\end{array}$ & $\begin{array}{l}\text { Market } \\
\text { timing }\end{array}$ & $\begin{array}{l}\text { Security } \\
\text { selection }\end{array}$ \\
\hline Constant $(\alpha)$ & $\begin{array}{l}0.00002 \\
(0.29)\end{array}$ & $\begin{array}{l}0.00012 \\
(0.57)\end{array}$ & $\begin{array}{l}0.00015^{\star \star} \\
(1.99)\end{array}$ & $\begin{array}{c}0.00026 \\
(0.92)\end{array}$ & $\begin{array}{l}0.00105^{\star \star \star} \\
(7.96)\end{array}$ & $\begin{array}{r}-0.00010 \\
(0.36)\end{array}$ \\
\hline \multicolumn{7}{|l|}{ Risk factors: } \\
\hline MKT-RF & $\begin{array}{c}-0.00011 \\
(0.07)\end{array}$ & $\begin{array}{c}-0.00206 \\
(0.52)\end{array}$ & $\begin{array}{c}-0.00068 \\
(0.38)\end{array}$ & $\begin{array}{c}0.00048 \\
(0.10)\end{array}$ & $\begin{array}{c}-0.01467^{\star \star \star} \\
(6.16)\end{array}$ & $\begin{array}{l}0.01551^{\star \star \star} \\
(3.30)\end{array}$ \\
\hline SMB & $\begin{array}{c}-0.00069 \\
(0.711)\end{array}$ & $\begin{array}{l}0.00041 \\
(0.09)\end{array}$ & $\begin{array}{c}0.00317 \\
(1.26)\end{array}$ & $\begin{array}{c}0.01096 \\
(1.50)\end{array}$ & $\begin{array}{c}0.01474^{\star * \star} \\
(3.66)\end{array}$ & $\begin{array}{r}0.00050 \\
(0.06)\end{array}$ \\
\hline HML & $\begin{array}{l}0.00313 \\
(0.76)\end{array}$ & $\begin{array}{l}0.01331 \\
(1.33)\end{array}$ & $\begin{array}{c}-0.00322 \\
(0.64)\end{array}$ & $\begin{array}{c}-0.01965^{\star} \\
(1.65)\end{array}$ & $\begin{array}{c}-0.01934^{\star \star \star} \\
(2.63)\end{array}$ & $\begin{array}{r}0.01193 \\
(0.93)\end{array}$ \\
\hline RMW & $\begin{array}{l}0.00149 \\
(0.61)\end{array}$ & $\begin{array}{l}0.00575 \\
(0.80)\end{array}$ & $\begin{array}{c}-0.00259 \\
(1.02)\end{array}$ & $\begin{array}{c}-0.00751 \\
(0.97)\end{array}$ & $\begin{array}{r}-0.00498 \\
(1.34)\end{array}$ & $\begin{array}{c}0.01414^{\star} \\
(1.81)\end{array}$ \\
\hline CMA & $\begin{array}{c}-0.00258 \\
(0.71)\end{array}$ & $\begin{array}{c}-0.00808 \\
(0.86)\end{array}$ & $\begin{array}{c}0.00225 \\
(0.46)\end{array}$ & $\begin{array}{c}0.00443 \\
(0.35)\end{array}$ & $\begin{array}{c}0.01807^{\star \star \star} \\
(2.74)\end{array}$ & $\begin{array}{c}-0.03995^{\star \star \star} \\
(3.45)\end{array}$ \\
\hline Number of obs. & 7,335 & 2,500 & 7,335 & 2,500 & 9,135 & 9,135 \\
\hline Number of pension funds & 342 & 172 & 342 & 172 & 380 & 380 \\
\hline Wald test & 2.64 & 4.58 & 4.75 & 6.67 & $64.40^{\star \star \star}$ & $35.57^{\star \star \star}$ \\
\hline
\end{tabular}

Note: Random coefficient estimates of the constant $(\alpha)$ when adjusting for five risk factors. The five Fama and French (2015) factors are: MKT-RF (excess market return), SMB (small-minus-big), HML (high-minus-low), RMW (robust-minus-weak profitability) and CMA (low-minus-high investment). $z$-values are given in parentheses. ${ }^{\star \star \star},{ }^{\star \star},{ }^{\star}$ denote significance at the $1 \%, 5 \%, 10 \%$ levels.

reasons. These motives will impact investment beliefs and therefore the extent to which proprietary benchmark returns deviate from standard benchmark returns. Regarding risk preferences, we hypothesise that corporate pension funds are more risk averse and prefer to stick to standard benchmarks. The risk profile of a corporate pension plan directly affects the sponsor's balance sheet due to accounting rules. Corporate pension plans may therefore perceive deviating from a standard benchmark as an additional source of risk. Regarding style preferences, we hypothesise that industry-wide pension funds are more inclined to have those. Industry-wide pension funds are the largest pension funds in the Netherlands and more exposed to public scrutiny. These pension funds will be more under pressure of stakeholders to, e.g., adopt a sustainable investment strategy, by tilting the portfolio towards green bonds or by excluding specific sectors from their equity portfolio. Table 8 shows the results for the Tobit regression.

The results suggest that large pension funds invest more closely to standard benchmarks, especially for equity and real estate. This is likely to be a mechanical effect as large pension funds typically need to diversify over a large pool of individual assets and thus are more likely to invest in the same assets as included in standard benchmarks. Table 8 also suggests that pension funds with more retirees have stronger investment beliefs concerning bonds and stocks. This indicates that retirees are more engaged with their pension savings. Furthermore it appears that corporate pension funds have no specific beliefs regarding any of the three asset classes as the proprietary benchmark returns do not statistically deviate from standard benchmark returns. This is consistent with our hypothesis. We also find that industrywide pension funds have particularly strong risk beliefs regarding equity. We believe this indicates that industry-wide pension funds are more exposed to 'headline risk' as in Goyal and Wahal (2008) because of their larger societal role. These pension funds are indeed more sensitive to public scrutiny so that they for instance would rather not invest in sin stocks or carbon intensive industries.

\section{Robustness check}

In Section 4, we explain how we clean the data for possible reporting errors and omissions based on comparing asset class returns with portfolio returns. As a consequence we prudently drop $18 \%$ of the 
Table 8. Benchmark selection and pension fund characteristics

\begin{tabular}{|c|c|c|c|}
\hline Asset class & Bonds & Stocks & Real estate \\
\hline Size & $\begin{array}{r}-0.0002 \\
(-0.67)\end{array}$ & $\begin{array}{c}-0.0016^{\star * *} \\
(-3.63)\end{array}$ & $\begin{array}{c}-0.0018^{\star *} \\
(-1.95)\end{array}$ \\
\hline Age & $\begin{array}{c}0.0068^{\star \star \star} \\
(2.39)\end{array}$ & $\begin{array}{c}0.0238^{\star \star \star} \\
(3.93)\end{array}$ & $\begin{array}{r}-0.0004 \\
(-0.05)\end{array}$ \\
\hline Industry-wide pension funds & $\begin{array}{r}0.0014 \\
(0.53)\end{array}$ & $\begin{array}{c}0.0076^{\star \star \star} \\
(2.27)\end{array}$ & $\begin{array}{r}-0.0040 \\
(-0.51)\end{array}$ \\
\hline Corporate pension fund & $\begin{array}{r}0.0002 \\
(0.06)\end{array}$ & $\begin{array}{r}0.0037 \\
(1.13)\end{array}$ & $\begin{array}{c}-0.0033 \\
(-0.44)\end{array}$ \\
\hline Constant & $\begin{array}{c}0.0378^{\star \star \star} \\
(8.62)\end{array}$ & $\begin{array}{c}0.0347^{\star \star \star *} \\
(5.52)\end{array}$ & $\begin{array}{c}0.1149^{\star * *} \\
(7.93)\end{array}$ \\
\hline Number of obs. & 422 & 422 & 422 \\
\hline Log-likelihood & $1,269.3$ & $1,151.8$ & 786.1 \\
\hline
\end{tabular}

Note: Tobit estimates of the standard deviation of the quarterly return differences between the reported proprietary and standard benchmarks on pension fund characteristics. Robust standard errors are given in parentheses. ${ }^{* \star *},{ }^{* \star},{ }^{*}$ denote significance at the $1 \%, 5 \%$, $10 \%$ levels.

quarterly observations from the data. We cannot determine with certainty however that these are true reporting errors and omissions. Possibly, different treatments of currency and other derivatives overlays in reporting may cause differences between reported and calculated portfolio returns. As a robustness check we therefore run all our regressions using the full sample. The findings in this case are overall comparable to those in the main analysis. ${ }^{15}$ The last two rows in Table 3 show the mean total returns and standard deviations for the full sample. Based on this, the strategic asset allocation explains $87 \%$ of actual returns, benchmark selection 5\%, timing $9 \%$ and selection 5\%, respectively. Hence, asset allocation remains the main driver of returns. Obviously, standard errors are larger in this case as it includes the 'outliers'. If we assess the drivers of cross-sectional return variation we see that benchmark selection is still key. Based on the full sample, asset allocation explains on average $9.6 \%$ of the cross-sectional variation in pension fund returns. Benchmark selection explains $25.7 \%$, timing contributes $15.0 \%$ and security selection $25.2 \%$. We can compare these numbers to Table 5 , panel B.

\section{Conclusion}

Based on mandatory reporting of Dutch pension funds, we analyse the four key decisions that drive their investment returns: asset allocation, benchmark selection, market timing and security selection. Benchmark selection is innovative to the literature and reflects decisions on the investment universe of a pension fund. A pension fund with a specific investment universe uses a proprietary benchmark instead of a standard benchmark for return evaluation. The benchmark also serves as a threshold for the investment manager's compensation. Our key findings are as follows.

\section{Return decomposition}

Measured over time and across pension funds, on average the strategic asset allocation decision comprises $82 \%$ of total return. The contribution of benchmark selection to total return is on average positive and determines $8 \%$ of total returns. Benchmark selection is more important than timing and security selection. However, it is also fair to say that benchmark selection contributes negatively to the overall return in half of the years in the sample.

\section{Contributions to return variation}

When we focus on time series and cross-sectional effects separately, the results are different. Over time, asset allocation explains $39 \%$ of the variation of pension funds' returns, whereas benchmark

\footnotetext{
${ }^{15}$ Tables are available upon request.
} 
selection, timing and selection explain $11 \%, 9 \%$ and $16 \%$, respectively. Across pension funds, benchmark selection explains 33\% of cross-sectional returns, whereas asset allocation explains only $19 \%$. Selecting the investment universe therefore matters in comparing returns between pension funds.

\section{Contributions to return variation net of market movements}

After correcting for market movements, benchmark selection explains $35 \%$ of the time variation of returns. Benchmark selection is in this case more important than the asset allocation decision.

\section{Returns from actively changing strategic asset allocation}

Changing the strategic asset allocation policy over time does not produce additional returns per quarter. Also not if we consider only those pension funds changing their strategic asset allocation. This means that we cannot confirm the results of Andonov et al. (2012) who do find abnormal returns from US pension funds changing their asset allocation policy across broader asset classes over time.

\section{Risk-adjusted returns from actively changing strategic asset allocation}

After risk-adjustment, the changes in the strategic asset allocation again do not have a significant effect on returns. However, we find that market timing delivers a positive $\alpha$ of 0.11 basis point per quarter. Market timing has a positive loading on the SMB and CMA factors and a negative loading on the market and HML factors. All these four are statistically significant. Security selection on the other hand does not produce additional returns but has a positive factor loading on the market and a negative on CMA.

Which investment decision - asset allocation, benchmark selection, market timing or security selection - is most important for institutional investors? This has been an important debate in the finance literature. The seminal work of Brinson et al. (1986) focuses on the importance of the asset allocation decision in explaining return variation over time. Ibbotson and Kaplan (2000) show that asset allocation policy explains more than $100 \%$ of the level of returns. Both authors, however, also demonstrate that asset allocation policy explains $90 \%$ of return variability over time and $40 \%$ of cross-sectional differences in returns among pension funds. The latter finding is confirmed by Andonov et al. (2012) who find that security selection explains most of the differences in pension fund returns.

We extend the logic of Ibbotson and Kaplan (2000) that the importance of an investment decision can only be interpreted against the question one wishes to answer. The answer to the question 'which decision matters most' is not straightforward and depends on the framing of that question. In this paper, we are the first to show that benchmark selection matters. The choice of a proprietary benchmark reflects a pension fund's investment universe. We show that this investment decision matters significantly in explaining return differences between pension funds. We finally document that pension fund characteristics influence benchmark selection. Large pension funds invest more closely to standard benchmarks for mechanical diversification reasons, and pension funds with more retirees have stronger investment preferences following greater engagement of the elderly with their pension savings. We also find that corporate pension funds have no specific beliefs or preferences regarding any of the three asset classes. This is likely to be related to low risk preferences as deviating from a standard benchmark is an additional source of risk for this type of funds. Finally, we find evidence that industry-wide pension funds have particularly strong risk beliefs regarding equity. We suggest that this indicates that industry-wide pension funds are more exposed to public scrutiny through 'headline risk'.

Acknowledgements. Views expressed are those of the authors and do not necessarily reflect official positions of De Nederlandsche Bank. We thank two anonymous referees, Aleksandar Andonov, Matteo Bonetti, Bart Bos, Kristy Jansen 
and participants of seminars at DNB and EPFIF for useful comments. Moreover, we are grateful to David Keijzer for the data gathering process and Henk van Kerkhoff for data handling.

\section{References}

Andonov A, Bauer RMMJ and Cremers KJM (2012) Can large pension funds beat the market? Asset allocation, market timing, security selection and the limits of liquidity. Available at ssrn.com/abstract $=1885536$.

Andreu L, Ferruz L and Vicente L (2010) The importance of asset allocation in Spanish equity pension plans. Journal of Pension Economics and Finance 9, 129-142.

Bauer RMMJ, Cremers KJM and Frehen RGP (2010) Pension fund performance and costs: small is beautiful. Available at ssrn.com/abstract $=965388$.

Bikker JA, Broeders DWGA and de Dreu J (2010) Stock market performance and pension fund investment policy: rebalancing, free float, or market timing? International Journal of Central Banking 6, 53-79.

Blake D, Lehmann BN and Timmermann A (1999) Asset allocation dynamics and pension fund performance. Journal of Business 72, 429-461.

Brinson GP, Hood LR and Beebower GL (1986) Determinants of portfolio performance. Financial Analysts Journal 42, $39-44$.

Brinson GP, Singer BD and Beebower GL (1991) Determinants of portfolio performance II: an update. Financial Analysts Journal 47, 40-48.

Broeders DWGA and Ponds EHM (2012) Dutch pension system reform: a step closer to the ideal system design. CESifo DICE Report 3, 65-76.

Broeders DWGA, van Oord JA and Rijsbergen DR (2017) Does it pay to pay performance fees? Empirical evidence from Dutch pension funds. Journal of International Money and Finance 93, 299-312.

Brown KC, Garlappi L and Tiu C (2010) Asset allocation and portfolio performance: evidence from university endowment funds. Journal of Financial Markets 13, 268-294.

Clare A, Nitzsche D and Cuthbertson K (2010) An empirical investigation into the performance of UK pension fund managers. Journal of Pension Economics and Finance 9, 533-547.

Davis P and de Haan L (2012) Pension fund finance and sponsoring companies. Journal of Pension Economics and Finance 11, 439-463.

De Haan L (2018) Recovery measures of underfunded pension funds: higher contributions. No indexation, or pension cuts? Journal of Pension Economics and Finance 17, 437-468.

De Nederlandsche Bank (DNB) (2011) Rapport beleggingsopbrengst pensioenfondsen 2000-2010 (in het kader van de motie Van den Besselaar c.s.). November.

Drobetz W and Köhler F (2002) The contribution of asset allocation policy to portfolio performance. Financial Markets and Portfolio Management 16, 219-233.

Fama EG and French KR (2015) A five-factor asset pricing model. Journal of Financial Economics 116, 1-22.

Gerritsen M (2016) De beleggingsrendementen van de Nederlandse pensioenfondsen. Economisch Statistische Berichten 101, 340-343.

Goyal A and Wahal S (2008) The selection and termination of investment management firms by plan sponsors. Journal of Finance 63, 1805-1847.

Grinold RC and Kahn RN (2000) Active Portfolio Management: A Quantitative Approach for Providing Superior Returns and Controlling Risk, 2nd Edn. New York: McGraw-Hill.

Heale M, Beath AD and Heuberger E (2018) Hedge fund reality check. CEM Benchmarking. Available at: https://cembench marking.com/ri/insight/15.

Huang X and Mahieu RJ (2012) Performance persistence of Dutch pension funds. De Economist 160, 17-34.

Ibbotson RG and Kaplan PD (2000) Does asset allocation policy explain 40, 90 or 100 percent of performance? Financial Analysts Journal 56, 26-33.

OECD (2017) Pension Markets in Focus. Available at http://www.oecd.org/pensions/private-pensions/Pension-Markets-inFocus-2017.pdf.

Swamy PAVB (1970) Efficient inference in a random coefficient regression model. Econometrica 38, 311-323.

van Binsbergen JH, Brandt M and Koijen RSJ (2008) Optimal decentralized investment management. Journal of Finance 63, 1849-1895.

Xiong JX, Ibbotson RG, Idzorek TM and Chen P (2010) The equal importance of asset allocation and active management. Financial Analysts Journal 66, 22-30. 


\section{Appendix: A closer look at returns from market timing}

Timing involves an active decision to over or underweight a specific asset class relative to the strategic asset allocation. Earning additional returns from market timing is difficult. This is because timing decisions typically have a low frequency and predicting market movements is particularly difficult. We already mentioned that the overall mean return from timing across pension funds and time is $0.10 \%$ (Table 3 ). To see whether pension funds differ in success between overweight versus underweight decisions, we split the return from timing into the return from overweight and the return from underweight decisions (Table A1). The average return across pension funds and time of overweighting asset classes is $0.11 \%$ per quarter. This compares to an average return of $-0.02 \%$ of underweighting asset classes. Apparently pension funds are more successful when deciding to overweight a certain asset class.

Table A1. Decomposition of quarterly pension fund returns from market timing into under and overweight decisions

\begin{tabular}{|c|c|c|c|c|c|c|}
\hline Year & & $\begin{array}{l}(1) \\
R^{M T}\end{array}$ & $\begin{array}{c}(2) \\
R^{M T+}\end{array}$ & $\begin{array}{c}(3) \\
R^{M T-}\end{array}$ & $\begin{array}{l}(4) \\
\text { Obs. }\end{array}$ & $\begin{array}{c}\text { (5) } \\
\text { Pension funds }\end{array}$ \\
\hline \multirow[t]{2}{*}{2007} & Mean & 0.0008 & 0.0007 & 0.0001 & 1,223 & 381 \\
\hline & Std & 0.0031 & 0.0022 & 0.0019 & & \\
\hline \multirow[t]{2}{*}{2008} & Mean & 0.0044 & 0.0002 & 0.0042 & 982 & 350 \\
\hline & Std & 0.0095 & 0.0048 & 0.0070 & & \\
\hline \multirow[t]{2}{*}{2009} & Mean & -0.0004 & 0.0011 & -0.0015 & 1,157 & 364 \\
\hline & Std & 0.0138 & 0.0123 & 0.0078 & & \\
\hline \multirow[t]{2}{*}{2010} & Mean & 0.0010 & 0.0017 & -0.0007 & 1,008 & 325 \\
\hline & Std & 0.0047 & 0.0031 & 0.0039 & & \\
\hline \multirow[t]{2}{*}{2011} & Mean & 0.0005 & 0.0007 & -0.0001 & 1,000 & 324 \\
\hline & Std & 0.0051 & 0.0032 & 0.0035 & & \\
\hline \multirow[t]{2}{*}{2012} & Mean & 0.0004 & 0.0016 & -0.0011 & 1,055 & 312 \\
\hline & Std & 0.0035 & 0.0033 & 0.0027 & & \\
\hline \multirow[t]{2}{*}{2013} & Mean & 0.0006 & 0.0010 & -0.0003 & 1,028 & 286 \\
\hline & Std & 0.0035 & 0.0029 & 0.0025 & & \\
\hline \multirow[t]{2}{*}{2014} & Mean & 0.0013 & 0.0025 & -0.0012 & 910 & 266 \\
\hline & Std & 0.0039 & 0.0041 & 0.0024 & & \\
\hline \multirow[t]{2}{*}{2015} & Mean & 0.0005 & 0.0006 & -0.0001 & 550 & 188 \\
\hline & Std & 0.0042 & 0.0040 & 0.0036 & & \\
\hline \multirow[t]{2}{*}{2016} & Mean & 0.0001 & 0.0013 & -0.0012 & 461 & 177 \\
\hline & Std & 0.0033 & 0.0027 & 0.0022 & & \\
\hline \multirow[t]{2}{*}{ Total } & Mean & 0.0010 & 0.0011 & -0.0002 & 9,374 & 455 \\
\hline & Std & 0.0069 & 0.0054 & 0.0046 & & \\
\hline
\end{tabular}

Note: The table reports the summary statistics as of Table 3 for the average return contribution from market timing $R^{M T}$, split into the return from overweight and the return from underweight decisions.

Cite this article: Broeders D, de Haan L (2020). Benchmark selection and performance. Journal of Pension Economics and Finance 19, 511-531. https://doi.org/10.1017/S1474747219000246 